\title{
Proactive Coping as the Moderator of Hope and Subjective Well-Being Among Micro, Small, and Medium Enterprises Actors During Pandemic
}

\author{
Savrine Purnama ${ }^{1}$ Riana Sahrani ${ }^{1 *}$ \\ ${ }^{1}$ Faculty of Psychology, Universitas Tarumanagara, West Jakarta, Indonesia \\ *Corresponding author. Email: rianas@fpsi.untar.ac.id
}

\begin{abstract}
The outbreak of Coronavirus Disease (COVID-19) around the world had impacted negatively on global economic. Many countries had entered recession due to the imposition of lockdowns to prevent the spread of COVID-19, including Indonesia which had imposed Large-Scale Social Restrictions (LSSR). As a result, many Micro, Small and Medium Enterprises (MSME) actors were affected by this issue and impacted with many losses in their business, even many MSME actors were threatened with bankruptcy. This problem could certainly impact the Subjective Well-Being (SWB) of MSME actors. In fact, SWB has many useful benefits for MSME actors to maintain and develop their business in current situation. Several ways that could be applied to develop SWB were to have hope and implement proactive coping. When the goals of MSME actors could be achieved, this could increase the SWB of MSME actors. This study aimed to examine the role of proactive coping as a moderator between hope and SWB. Participants in this study included 221 MSME actors in Jakarta who have been running their business for at least one year. The results showed that both hope and proactive coping can have a significant role on SWB with an effect of $29.7 \%$. However, proactive coping did not have moderating effect on the relationship between hope and SWB.
\end{abstract}

Keywords: Subjective well-being, hope, proactive coping, MSME, entrepreneur

\section{INTRODUCTION}

Coronavirus Disease 2019 (COVID-19) is an infectious disease that causes a respiratory tract infection in both humans and animals. The COVID-19 outbreak first appeared in Wuhan, China in December 2019 and has spread throughout the world, including Indonesia [1], [2]. Globally, the positive cases of COVID-19 as per $21^{\text {st }}$ September 2019 had reached over 30 million cases, whereas in Indonesia itself had reached over 240 thousand cases. This had led many countries to implement lockdowns, and also Large-Scale Social Restriction (also known as LSSR) in Indonesia.

Large-Scale Social Restrictions (LSSR) are policies implemented by the Indonesian government to prevent the spread of the COVID-19, which limiting activities in public places infected with the COVID-19 [3], [4]. The Minister of Finance, Sri Mulyani, revealed that LSSR policy in various regions in Indonesia had impacted negatively in Indonesian economy, even caused recession [5], [6]. This economic decline was due to various business sectors having an economic slowdown and many micro, small, and medium enterprises (MSMEs) also having loss of demands during the LSSR period [7], [8].

As the majority business in Indonesia, MSMEs has an important role for Indonesian economy. Central Bureau of
Statistics (BPS) noted that MSMEs in Indonesia had reached $99.9 \%$ of allover businesses [9]. In normal condition, MSMEs contributed 60\% to Gross Domestic Product nationally, $96 \%$ to national employment, $14 \%$ of total exports, and were the dominant sector in driving economic growth. During the economic crisis in 1998, MSMEs was also the rescuer of Indonesian economy because they're still able to survive [10]. However, MSMEs, which can be the rescuer and motor of Indonesian economy, are the most affected business sectors due to this pandemic [9].

Head of the Presidential Staff Office, Moeldoko, also stated that MSME actors had a decrease in income due to the decline in people's purchasing power, which in turn decreasing the demand for their products. Furthermore, another problem is the inability of MSME actors to finance their business due to running out of business capital [11]. Many MSMEs also had problems in the availability of raw materials and credits payment [12].

These economic impacts certainly have given an adverse effect on MSME actors, since they still have to struggle to meet the needs of their lives and their families [13]. According to the survey result of Lembaga Survei Indikator Politik Indonesia, $34.8 \%$ of business actors were very worried and $49.9 \%$ of business actors were quite worried about the COVID-19 outbreak [14]. Deputy Chair of the 
Indonesian Employers' Association, Shinta Kamdani (in [15]) also admitted that she was worried about the reintroduction of the total LSSR in early September 2020 for a long time, because it could make many MSMEs unable to survive, if there were no satisfactory results in efforts to control COVID -19. Setiawan [16] also reported that many businessmen were more worried about a prolonged pandemic since it might cause bigger problems, such as higher layoffs, an increase in poverty, and more MSMEs would not be able to survive. The government had also made various efforts to aid MSME actors, but the efforts seemed not optimal yet [17].

Nisfiannor et al. [18] stated if individuals cannot overcome their problem, it would cause unpleasant emotion, even made the individuals feel dissatisfied and unhappy with their life. The feelings of dissatisfaction and unhappiness in life can lower an individual's subjective well-being, where the components of subjective well-being consists of life satisfaction and frequently feel positive affect [19]. Thus, it may have an impact on decreasing the subjective well-being of MSME actors, whom still has not been able to overcome the various problems they have been experiencing. In fact, subjective well-being can function as a protector from psychological distress and as a psychological resources that have various benefits [20], [21].

Subjective well-being (SWB) is a subjective assessment made by an individual regarding his life satisfaction, both generally or specifically, and regarding the frequently positive affect felt by the individual [22], [23]. de Neve et al. [24] and Wiklund et al. [21] noted that SWB could make individuals healthier and have a longer life, more productive, creative and flexible at work, and have a social connection. SWB was also found could increase altruism, prosocial behavior, effective problem solving skill, strong immunity, and open-minded [25]-[27]. Seeing the various benefits of SWB, SWB is very important to be taken care for MSME actors. If MSME actors have a high SWB, then MSME actors will be able to face and overcome various challenges that occur during this uncertain pandemic. Increasing SWB can be done by developing hope [28]-[31]. Hope is a positive motivational state that is felt by individuals due to the thoughts about planning and an strong will to reach a goal, as well as individuals perception of their abilities to create a goal [32]-[34]. According to Snyder theory of hope (in [29]), when individuals have high hope, it will increase their creativity and perseverance, resulting in making them see more opportunities in reaching their goals. Thus, they will feel happy because their goals are achievable and they also will feel satisfied with their lives for the success they have achieved. Other researchers also found that hope could enhance self-esteem, problem solving skill, optimism, perception of control in life, positive affectivity, and life satisfaction [28]-[31], [35]-[37].

Another thing that can enhance SWB is proactive coping. Through proactive coping, individuals gather various resources that can facilitate their personal growth, reaching their challenging goals, as well as creating new opportunities. They also see stressor as a challenge instead of a threat [38]-[40]. Many studies found that proactive coping could predict purpose in life, personal growth, life satisfaction, and also positive affect [40]-[45].

Although previous research have found strong correlation between hope and SWB (i.e. [29]-[31]), but those researches were conducted in normal condition. Study conducted during pandemic by Satici et al. [46] has found a weak correlation between hope and SWB. Research by Counted et al. [47] also conducted a moderator testing on the relationship between hope and SWB during pandemic. $\mathrm{He}$ also stated that the role of hope which can increase SWB can be decreased due to stress due to disasters, so that maybe hope is not enough to deal with stress during a pandemic.

Based on the explanations above, we see that proactive coping is important to be applied in this uncertain pandemic, especially for MSME actors. In addition to the need to minimize the impact of possible threats, MSME actors also need to think about breakthrough strategies (proactive coping), so that they can reverse the situation and their business will become more developed. Thus, it will also improve the country's economy as well. Therefore, present study aims to examine the role of proactive coping as the moderator between hope and subjective well-being.

\section{THEORETICAL STUDY}

\subsection{Hope}

According to Snyder [48] and Snyder et al. [33], hope can be defined as a cognitive process or positive motivational state that involves an interactive and reciprocal relationship between the drive that leads to goals (agency) and planning to achieve these goals (pathways). Hope can also be interpreted as individuals' perception of their ability to produce a goal, think of various ways to achieve that goal, and use the drive that leads to that goal effectively [34], [48]. The two components of hope are pathways thoughts and agency thoughts. Pathways thoughts are individuals' perception of their abilities in creating various effective ways to achieve their goal. It also involves creating alternative ways when facing an obstacle during goalattainment process [48]-[50]. Agency thoughts are individuals' perception of their abilities in using the pathways. Agency thoughts are the motivational component of hope which plays a role in driving individuals to start the goal-attainment actions and keeping that actions until the specified goals are achieved [48]-[50]

Hope is different with self-efficacy. Although self-efficacy refers to individuals' perception towards their ability to achieve their goals and outcome expectations which are similar to agency hope, but hope also involves pathways and reciprocal relationship between agency and pathways in achieving the goals [37], [51]. Hope is also different with optimism. While optimism focuses only on the positive attributes of an event and seems like a way to avoid negative outcomes, hope also focuses on goal achievement by making use of its components [37], [51]. 


\subsection{Proactive Coping}

Schwarzer and Taubert [52] states that proactive coping is the efforts made by individuals to gather various resources that can facilitate personal growth and achieve challenging goals, as well as creating new opportunities. Individuals have a goal and see the future stressor as a challenge instead of a threat. This coping is more of goal management rather than risk management. Individuals are proactive in creating constructive actions and opportunities for growth [40], [52]. Schwarzer (in [53]) reveals that proactive coping is different with the traditional coping which is reactive to the occurring stressor. Proactive coping is more futureoriented, while traditional coping aims to compensate for threats that have already occurred. Proactive coping is also more of goal-management, whereas traditional coping is more of risk management. In addition, proactive coping is more positive because it sees demand as a challenge, in contrast to traditional coping which sees the demand as a threat. Proactive coping is also different with preventive coping. Although both of them are future-oriented, the motivation generated in proactive coping is more due to seeing the demands as a challenge, whereas preventive coping is more due to seeing demands as a threat, so that the fear in proactive coping is also smaller than in prevention coping [40], [52], [54]. In addition, proactive coping makes people take purposeful actions, while preventive coping is more about collecting defensive strategies to save various resources needed in the future [42].

\subsection{Subjective Well-Being}

Diener et al. [55] states that SWB is an evaluation made by an individual regarding their life in terms of cognitive and affective. SWB can also be defined as an individuals' subjective evaluation regarding their life satisfaction (cognitive), both generally or specifically, and frequent positive affect felt by the individual instead of the negative affect [22], [23], [56]. Diener [19], [56] reveals that SWB can be characterized by three things. First, SWB is subjective, which means that each individual can have a different experience. Second, SWB also measures positive experiences, not just the absence of negative experiences. Third, SWB also measures individuals' assessment of their life as a whole. Proctor [57] also stated that people with high SWB felt satisfied with their life and feel frequent positive affect instead of negative affect. Conversely, people with low SWB experience more frequent life dissatisfaction and negative affect, and less often experience positive affect.

According to Diener [19], SWB consists of two components, namely cognitive components and affective components. The cognitive components refer to the domain satisfaction and life satisfaction in general. Although domain satisfaction can be measured, SWB focuses more on life satisfaction in general. Life satisfaction can be defined as individuals' cognitive evaluation of their lives as a whole. On the other side, affective component comprises of positive affect, which can be defined as positive emotions experienced by individuals; and negative affect, which can be defined as negative emotions experienced by individuals.

\section{METHODS}

Sampling method that the authors used was purposive sampling. Participants in this study are $221 \mathrm{MSME}$ actors in DKI Jakarta who have been running their own businesses for at least one year.

Data collection were conducted via online using google form that were distributed through social media and ecommerce, and via offline which were distributed at Pasar Tanah Abang, Mangga Dua Square, and Thamrin City, using health protocols recommended by the government (face shield and mask). Further, the collected data was analyzed using Statistical Product and Service Solution (SPSS) version 25.

The measuring instrument we used in this study were Adult Hope Scale developed by Snyder et al. [33], which has been translated into Indonesian by Kurniadi et al. [58] and consisted of 12 items; Proactive Coping Subscale of Proactive Coping Inventory (PCI) developed by Greenglass et al. [54] which consisted of 14 items; and Positive Affect and Negative Affect Schedule developed by Watson et al. [59] to measure the affective component of SWB, and Satisfaction With Life Scale developed by Diener et al. [60] to measure the cognitive component of SWB. These measures have been adapted into one SWB measure in Indonesian by The Research and Measurement Department of the Faculty of Psychology, Tarumanagara University. The scale consists of 22 items measuring negative affect, 22 items measuring positive affect, and 5 items measuring global life satisfaction

\section{RESULTS AND DISCUSSION}

\subsection{Results}

This study was conducted on 221 MSME actors, comprise of 106 males (48\%) and 115 females (52\%), with age ranging from 16-70 years in DKI Jakarta. Descriptive statistical analysis using SPSS was conducted and the result showed that hope has mean score $3.351(\mathrm{SD}=0.425)$, proactive coping has mean score $3.244(\mathrm{SD}=0.441)$, and SWB has mean score $3.061(\mathrm{SD}=0.437)$. Spearman's correlation was conducted to test the correlation between AHS with SWB measurement $\left(\mathrm{r}_{\mathrm{s}}(221)=0.550, p<0.001\right)$. This result indicated the higher the hope, the SWB will be higher. Pearson correlation was also conducted to test the correlation between Proactive Coping Subscale with SWB measurement $(\mathrm{r}(221)=0.483, p<0.001)$. This result also indicated the higher the hope, the SWB will be higher. These results can be seen in Table 1 . 
Table 1 Bivariate correlations between variables

\begin{tabular}{lcc}
\hline Variables & Subjective Well-Being & $\boldsymbol{p}$ \\
\hline Hope & 0.550 & 0.000 \\
Proactive Coping & 0.483 & 0.000 \\
\hline
\end{tabular}

To test moderation effect, we first conducted simple linear regression between hope with $\mathrm{SWB}$, and proactive coping with SWB. Results showed that hope significantly predicted SWB $(B=0.513, \mathrm{R} 2=0.248, p<0.001)$, and proactive coping also significantly predicted $\mathrm{SWB}(B=0.479, \mathrm{R} 2=$ $0.234, p<0.001)$. Further, we conducted multiple linear regression and results showed that hope and proactive coping together significantly predicted SWB $(\mathrm{F}(2,218)=$ $46.139, \mathrm{R} 2=0.297, p<0.001)$. Finally, interaction of hope $\mathrm{x}$ proactive coping was included in the multiple regression analysis. Results showed that proactive coping did not moderate the relationship between hope with SWB $(B=$ $0.042, t(219)=0.374, p=0.709)$. These results showed that proactive coping cannot moderate the relationship between hope and subjective well-being. Instead, proactive coping acts more as a second independent variable. This result can be seen in Table 2 .

Table 2 Summary statistics for regression analysis

\begin{tabular}{|c|c|c|c|c|}
\hline \multirow[t]{2}{*}{ Independent Variable } & \multicolumn{4}{|c|}{ Dependent Variable: Subjective Well-Being } \\
\hline & $\boldsymbol{B}$ & $\mathbf{F}$ & R2 & $p$ \\
\hline Simple Linear Regression: Hope & $0.513 * *$ & 72.342 & 0.248 & 0.000 \\
\hline Simple Linear Regression: Proactive Coping & $0.479 * *$ & 66.791 & 0.234 & 0.000 \\
\hline Multiple Linear Regression (Without Interaction) & & 46.139 & 0.297 & $\mathbf{0 . 0 0 0}$ \\
\hline Hope & $0.332 * *$ & & & 0.000 \\
\hline Proactive Coping & $0.280 * *$ & & & 0.000 \\
\hline Multiple Linear Regression (Interaction Included & & 30.684 & 0.298 & 0.000 \\
\hline Hope & 0.195 & & & 0.601 \\
\hline Proactive Coping & 0.144 & & & 0.697 \\
\hline Hope x Proactive Coping & 0.042 & & & 0.709 \\
\hline
\end{tabular}

$* * p<0.001$

\subsection{Discussions}

The purpose of this study is to examine whether proactive coping can moderate the relationship between hope with SWB. The results showed that proactive coping did not have moderating effect on the relationship between hope with SWB. According to Baron and Kenny [61], the moderator hypothesis testing can be supported if the interaction between the independent variable and the moderator is significant. However, the both variables must be normally distributed. In this study, hope, which acts as the independent variable, is not normally distributed, so it is likely that it can affect the interaction between hope and proactive coping to be insignificant to SWB.

However, the multiple regression analysis showed that proactive coping could act as the second independent variable. This finding is supported by other researches which also found that proactive coping predicts components in SWB [41], [43]-[45]. According to the theory of proactive coping proposed by Schwarzer, proactive individuals see the potential stressor as a challenge, so that it can motivate the individuals and creates opportunities for personal growth. The motivation occurred also can increase individuals' positive affect [43]. Individuals with proactive coping also experience less negative affect, because the stress is perceived as a challenge, not as a threat [42]. Furthermore, proactive coping can make individuals create opportunities for personal growth and take actions to achieve goals, so it can increase their life satisfaction due to the achieved goals [41], [52].
This study also found that hope correlate positively with SWB and predict SWB, which are in line with research conducted by Counted et al. [47], Pleeging et al. [29], Satici [46], and Werner [31], that also found hope had a positive correlation with SWB and could predict SWB. According to Snyder's Hope theory, hopeful individuals can achieve their goals due to the increased creativity and perseverance, so that it can give happiness and increase the life satisfaction when the goals are achieved. This theory also can be supported by the research conducted by Klug and Maier [62], which found that successful goal striving could increase individuals' SWB.

There are several limitations in this study. First, the data collected in this study is not normally distributed for hope variable, thus it might affect the analysis in the moderator testing. Second, the instruments in this study have many total items, so it can affect participants' commitment in filling out the questionnaire. Third, the authors did not limit the age and latest education, and the field of business they belonged to, thus allowing for individual differences.

\section{CONCLUSIONS}

In this study, we found that proactive coping did not moderate the relationship between hope and SWB. Hence, the hypothesis in this study is rejected. However, we found that proactive coping can act as the second the independent variable, which can predict SWB positively. Therefore, the higher the proactive coping, the SWB will be higher. Likewise, hope also predict SWB positively. The higher the hope, the SWB will be higher as well. 
We suggest further research to examine this study in big company businessman, since the big company also adversely affected by the pandemic and the problems in big company might also affect its employees.

\section{REFERENCES}

[1] World Health Organization, "WHO Coronavirus Disease (COVID-19) dashboard." [Online]. Available: https://covid19.who.int/. [Accessed: 09-Sep-2020]

[2] World Health Organization, "Pertanyaan dan jawaban terkait Coronavirus." [Online]. Available: https://www.who.int/indonesia/news/novel-coronavirus/ qa-for-public

[3] S. O. Alam, "Jokowi sebut beruntung pilih PSBB, ini bedanya dengan lockdown," detikHealth, 2020 [Online]. Available: https://health.detik.com/berita-detikhealth/d5005637/jokowi-sebut-beruntung-pilih-psbb-inibedanya-dengan-lockdown

[4] R. K. Dewi, "Mengenal apa itu PSBB, aturan, daerah yang menerapkan hingga sanksinya," Kompas.com, 14Apr-2020 [Online]. Available: https://www.kompas. com/tren/read/2020/04/14/093800065/mengenal-apaitu-psbb-aturan-daerah-yang-menerapkan-hinggasanksinya?page $=$ all

[5] CNN Indonesia, "Sri Mulyani sebut kebijakan PSBB 'Pukul' ekonomi RI," CNN Indonesia, 2020 [Online]. Available: https://www.cnnindonesia.com/ekonomi/ 20200511132615-532-502066/sri-mulyani-sebutkebijakan-psbb-pukul-ekonomi-ri

[6] H. Kusuma, "Sri Mulyani pastikan RI resesi di akhir September 2020," detikFinance, 22-Sep-2020 [Online]. Available: https://finance.detik.com/berita-ekonomibisnis/d-5183135/sri-mulyani-pastikan-ri-resesi-diakhir-september-2020

[7] A. Laraspati, "Pelaku UMKM curhat ke pimpinan MPR soal dampak kebijakan PSBB," detikNews, 05May-2020 [Online]. Available: https://news.detik.com/ berita/d-5002808/pelaku-umkm-curhat-ke-pimpinanmpr-soal-dampak-kebijakan-psbb

[8] L. J. Sembiring, "Sederet fakta penyebab ekonomi RI drop 5,32\% kuartal II-2020," CNBC Indonesia, 06-Aug2020 [Online]. Available: https://www.cnbcindonesia. com/news/20200806085003-4-177780/sederet-faktapenyebab-ekonomi-ri-drop-532-kuartal-ii-2020

[9] T. Santia, "Berapa jumlah UMKM di Indonesia? Ini hitungannya," 04-Sep-2020 [Online]. Available: https://www.liputan6.com/bisnis/read/4346352/berapajumlah-umkm-di-indonesia-ini-hitungannya

[10] R. I. Putra and A. P. Situmorang, "Pilar ekonomi Indonesia di tengah ancaman resesi," Merdeka.com, 17Sep-2020 [Online]. Available: https://www.merdeka. com/khas/pilar-ekonomi-indonesia-di-tengah-ancamanresesi-midreport.html

[11] CNN Indonesia, "Moeldoko bicara tiga masalah UMKM selama pandemi," CNN Indonesia, 09-Oct-2020 [Online]. Available: https://www.cnnindonesia.com/ ekonomi/20201009162151-92-556606/moeldokobicara-tiga-masalah-umkm-selama-pandemi

[12] D. A. Putra, "Dampak Covid-19, mayoritas penjualan UMKM seluruh Indonesia turun," Liputan6.com, 03-Jun-2020 [Online]. Available: https://www.liputan6.com/bisnis/read/4269831/dampak -covid-19-mayoritas-penjualan-umkm-seluruhindonesia-turun

[13] G. Amanda, "Pengaruh Covid-19 pada penurunan omzet usaha mikro," Republika.co.id, 17-Jun-2020 [Online]. Available: https://republika.co.id/berita/ qc1dlc423/pwmgaruh-covid19-pada-penurunan-omzetusaha-mikro

[14] A. N. Yahya, "Survei indikator: 84,7 persen responden pelaku bisnis sangat khawatir terhadap wabah Covid-19," Kompas.com, 24-Jul-2020 [Online]. Available: https://nasional.kompas.com/read/2020/07/ 24/06575111/survei-indikator-847-persen-respondenpelaku-bisnis-sangat-khawatir-terhadap

[15] E. Catriana, "Jakarta terapkan PSBB total, pengusaha khawatir," Kompas.com, 10-Sep-2020 [Online]. Available: https://money.kompas.com/read/ 2020/09/10/141647126/jakarta-terapkan-psbb-totalpengusaha-khawatir

[16] K. Setiawan, "Alasan pengusaha lebih khawatir pandemi berkepanjangan ketimbang resesi," Tempo.co, 27-Sep-2020 [Online]. Available: https://bisnis.tempo. co/read/1390459/alasan-pengusaha-lebih-khawatirpandemi-berkepanjangan-ketimbangresesi/full\&view=ok

[17] D. M. Purnamasari, "Wapres akui upaya pemerintah bantu UMKM belum optimal," Kompas.com, 07-Oct2020 [Online]. Available: https://nasional.kompas.com/ $\mathrm{read} / 2020 / 10 / 07 / 17461601 /$ wapres-akui-upayapemerintah-bantu-umkm-belum-optimal

[18] M. Nisfiannor, Rostiana, and T. Puspasari, "Hubungan antara komitmen beragama dan subjective well-being pada remaja akhir di Universitas 
Tarumanagara," J. Psikol., vol. 2, no. 1, pp. 74-93, 2004 [Online]. Available: https://fdokumen.com/document/ hubungan-antara-komitmen-beragama-danrostianatriana-tersebut-terjadi-pada.html

[19] E. Diener, "Subjective well-being," Psychol. Bull., vol. 95, no. 3, pp. 542-575, 1984, doi: $10.4324 / 9781003008477-2$.

[20] P. Baiden, S. Tarshis, K. Antwi-Boasiako, and W. den Dunnen, "Examining the independent protective effect of subjective well-being on severe psychological distress among Canadian adults with a history of child maltreatment," Child Abus. Negl., vol. 58, pp. 129-140, 2016, doi: 10.1016/j.chiabu.2016.06.017. [Online]. Available: http://dx.doi.org/10.1016/j.chiabu.2016.06. 017

[21] J. Wiklund, B. Nikolaev, N. Shir, M.-D. Foo, and S. Bradley, "Entrepreneurship and well-being: Past, present, and future," J. Bus. Ventur., vol. 34, no. 4, pp. 579-588, 2019, doi: 10.1016/j.jbusvent.2019.01.002. [Online]. Available: https://www.sciencedirect.com/ science/article/pii/S0883902618308942\#bb0165

[22] E. Diener, E. M. Suh, R. E. Lucas, and H. L. Smith, "Subjective well-being: Three decades of progress," Psychol. Bull., vol. 125, no. 2, pp. 276-302, 1999, doi: 10.1006/pupt.1998.0157.

[23] E. Diener and K. Ryan, "Subjective well-being: A general overview," South African J. Psychol., vol. 39, no. 4, pp. 391-406, 2009, doi: 10.1177/ 008124630903900402. [Online]. Available: https:// journals.sagepub.com/doi/abs/10.1177/0081246309039 00402? journalCode $=$ sapc\#: : text $=$ Incontrast $\% 2 \mathrm{C}$ subjective well-being,subjective evaluations of their lives.\&text=They require respon- dents to,much they experience certain feelings.

[24] J. de Neve, E. Diener, L. Tay, and C. Xuereb, "The objective benefits of subjective well-being.," 2013.

[25] B. Erdogan, T. N. Bauer, D. M. Truxillo, and L. R. Mansfield, "Whistle while you work: A review of the life satisfaction literature," J. Manage., vol. 38, no. 4, pp. 1038-1083, 2012, doi: 10.1177/0149206311429379.

[26] S. Lyubomirsky, L. King, and E. Diener, "The benefits of frequent positive affect: Does happiness lead to success?" Psychol. Bull., vol. 131, no. 6, pp. 803-855, 2005, doi: 10.1037/0033-2909.131.6.803.

[27] M. R. Tamannaeifar and M. Motaghedifard, "Subjective well-being and its sub-scales among students: The study of role of creativity and selfefficacy," Think. Ski. Creat., vol. 12, pp. 37-42, 2014, doi: 10.1016/j.tsc.2013.12.003. [Online]. Available: http://dx.doi.org/10.1016/j.tsc.2013.12.003

[28] P. D. Parker, J. Ciarrochi, P. Heaven, S. Marshall, B. Sahdra, and N. Kiuru, "Hope, friends, and subjective well-being: A social network approach to peer group contextual effects," Child Dev., vol. 00, no. 0, pp. 1-9, 2014, doi: 10.1111/cdev.12308.

[29] E. Pleeging, M. Burger, and J. van Exel, "The relations between hope and subjective well-being: A literature overview and empirical analysis," Appl. Res. Qual. Life, 2019, doi: 10.1007/s11482-019-09802-4.

[30] V. Shenaar-Golan, "Hope and subjective well-being among parents of children with special needs," Child Fam. Soc. Work, pp. 1-11, 2015, doi: 10.1111/cfs.12241.

[31] S. Werner, "Subjective well-being, hope, and needs of individuals with serious mental illness," Psychiatry Res., vol. 196, pp. 214-219, 2012, doi: 10.1016/ j.psychres.2011.10.012. [Online]. Available: http://dx. doi.org/10.1016/j.psychres.2011.10.012

[32] C. R. Snyder, "Reality negotiation: From excuses to hope and beyond," J. Soc. Clin. Psychol., vol. 8, no. 2, pp. 130-157, 1989, doi: 10.1521/jscp.1989.8.2.130.

[33] C. R. Snyder et al., "The will and the ways: Development and validation of an individual-differences measure of hope," J. Pers. Soc. Psychol., vol. 60, no. 4, pp. 570-585, 1991, doi: 10.1037/0022-3514.60.4.570.

[34] C. R. Snyder, K. A. Lehman, B. Kluck, and Y. Monsson, "Hope for rehabilitation and vice versa," Rehabil. Psychol., vol. 51, no. 2, pp. 89-112, 2006, doi: 10.1037/0090-5550.51.2.89.

[35] T. C. Bailey, W. Eng, M. B. Frisch, and C. R. Snyder, "Hope and optimism as related to life satisfaction," J. Posit. Psychol., vol. 2, no. 3, pp. 168175, 2007, doi: 10.1080/17439760701409546.

[36] E. C. Chang, "Hope, problem-solving ability, and coping in a college student population: Some implications for theory and practice," J. Clin. Psychol., vol. 54, no. 7, pp. 953-962, 1998, doi: 10.1002/(SICI)1097-4679(199811)54:7<953::AIDJCLP9>3.0.CO;2-F

[37] C. R. Snyder, "Conceptualizing, measuring, and nurturing hope," J. Couns. Dev., vol. 73, pp. 355-360, 1995, doi: 10.4324/9781315083421-18.

[38] American Psychological Association, "Proactive coping," APA Dictionary of Psychology. [Online]. Available: https://dictionary.apa.org/proactive-coping 
[39] E. R. Greenglass, L. Fiksenbaum, and J. Eaton, "The relationship between coping, social support, functional disability and depression in the elderly," Anxiety, Stress Coping, vol. 19, no. 1, pp. 15-31, 2006, doi: $10.1080 / 14659890500436430$.

[40] R. Schwarzer and N. Knoll, "Proactive coping," in The encyclopedia of positive psychology, S. J. Lopez, Ed. Wiley-Blackwell, 2009, pp. 781-784.

[41] A. Dwivedi and R. Rastogi, "Proactive coping, time perspective and life satisfaction: A study on emerging adulthood," J. Health Manag., vol. 19, no. 2, pp. 264274, 2017, doi: 10.1177/0972063417699689.

[42] Ö. Ersen and R. Bilgiç, "The effect of proactive and preventive coping styles on personal and organizational outcomes: Be proactive if you want good outcomes," Cogent Psychol., vol. 5, no. 1, 2018 [Online]. Available: https://www.tandfonline.com/doi/full/10.1080/2331190 8.2018 .1492865

[43] E. R. Greenglass and L. Fiksenbaum, "Proactive coping, positive affect, and well-being," Eur. Psychol., vol. 14, no. 1, pp. 29-39, 2009, doi: 10.1027/10169040.14.1.29. [Online]. Available: https://www. researchgate.net/publication/237818602_Proactive_Cop ing Positive Affect and Well-Being Testing for Mediation_Using_Path_Ānalysis

[44] S. J. Sohl and A. Moyer, "Refining the conceptualization of a future-oriented self-regulatory behavior: Proactive coping," Pers. Individ. Dif., vol. 47, pp. 139-144, 2009, doi: 10.1016/j.paid.2009.02.013. [Online]. Available: http://dx.doi.org/10.1016/j.paid. 2009.02.013

[45] C. Sougleris and R. Ranzijn, "Proactive coping in community-dwelling older Australians," Int. J. Aging Hum. Dev., vol. 72, no. 2, pp. 155-168, 2011, doi: 10.2190/AG.72.2.d.

46] S. A. Satici, A. R. Kayis, B. Satici, M. D. Griffiths, and G. Can, "Resilience, hope, and subjective happiness among the Turkish population: Fear of COVID-19 as a mediator," Int. J. Ment. Health Addict., 2020, doi: 10.1007/s11469-020-00443-5.

[47] V. Counted, K. I. Pargament, A. O. Bechara, S. Joynt, and R. G. Cowden, "Hope and well-being in vulnerable contexts during the COVID-19 pandemic: Does religious coping matter?" J. Posit. Psychol., pp. 112, 2020, doi: 10.1080/17439760.2020.1832247. [Online]. Available: https://doi.org/10.1080/17439760. 2020.1832247
[48] C. R. Snyder, "Hypothesis: There is hope," in Handbook of hope: Theory, measures, and applications, C. R. Snyder, Ed. Academic Press, 2000, pp. 3-21.

[49] C. R. Snyder, "The past and possible futures of hope," J. Soc. Clin. Psychol., vol. 19, no. 1, pp. 11-28, 2000, doi: 10.1521/jscp.2000.19.1.11.

[50] C. R. Snyder, "Hope theory: Rainbows in the mind," Psychol. Inq., vol. 13, no. 4, pp. 249-275, 2002.

[51] L. M. Edwards, "Hope," in The encyclopedia of positive psychology, 1st ed., S. J. Lopez, Ed. WileyBlackwell, 2009, pp. 487-491.

[52] R. Schwarzer and S. Taubert, "Tenacious goal pursuits and striving toward personal growth: Proactive coping," in Beyond coping: Meeting goals, visions and challenges, E. Frydenberg, Ed. London: Oxford University Press, 2002, pp. 19-35.

[53] E. R. Greenglass and L. Fiksenbaum, "Frequently asked question regarding the Proactive Coping Inventory (PCI)," 2005. [Online]. Available: http://userpage.fuberlin.de/ health/pci_faq.pdf

[54] E. R. Greenglass, R. Schwarzer, D. Jakubiec, L. Fiksenbaum, and S. Taubert, "The Proactive Coping Inventory (PCI): A multidimensional research instrument," in 20th International Conference of the Stress and Anxiety Research Society (STAR), 1999, no. 12, pp. 1-18 [Online]. Available: https://goo.gl/evkcUX

[55] E. Diener, R. E. Lucas, and S. Oishi, "Subjective well-being: The science of happiness and life satisfaction," in Handbook of Positive Psychology, C. R. Snyder and S. J. Lopez, Eds. 2002, pp. 63-73.

[56] E. Diener, "Subjective well-being: The science of happiness and a proposal for a national index," Am. Psychol., vol. 55, no. 1, pp. 34-43, 2000, doi: 10.1037/0003-066X.55.1.34.

[57] C. Proctor, "Subjective well-being," Encyclopedia of quality of life and well-being research. Springer Reference, 2014.

[58] G. Kurniadi, E. T. Atmodiwirjo, and N. Soetikno, "Hubungan antara harapan dan stres orang tua yang memiliki anak dengan autisme," J. Muara Ilmu Sos. Humaniora, dan Seni, vol. 3, no. 2, pp. 358-366, 2019, doi: 10.24912/jmishumsen.v3i2.3860.

[59] D. Watson, L. A. Clark, and A. Tellegen, "Development and validation of brief measures of positive and negative affect: The PANAS Scales," $J$. 
Pers. Soc. Psychol., vol. 54, no. 6, pp. 1063-1070, 1988, doi: 10.1037/0022-3514.54.6.1063.

[60] E. Diener, R. A. Emmons, R. J. Larsen, and S. Griffin, "The satisfaction with life scale," J. Pers. Assess., vol. 49, no. 1, pp. 71-75, 1985, doi: 10.1207/ s15327752jpa4901.

[61] R. M. Baron and D. A. Kenny, "The moderatormediator variable distiction in social psychological research: Conceptual, strategic, and statistical consideratons," J. Pers. Soc. Psychol., vol. 51, no. 6, pp. 1173-1182, 1986, doi: 10.1037//0022-3514.51.6.1173.

[62] H. J. P. Klug and G. W. Maier, "Linking goal progress and subjective well-being: A Meta-analysis," $J$. Happiness Stud., vol. 16, no. 1, pp. 37-65, 2014, doi: 10.1007/s 10902-013-9493-0. 